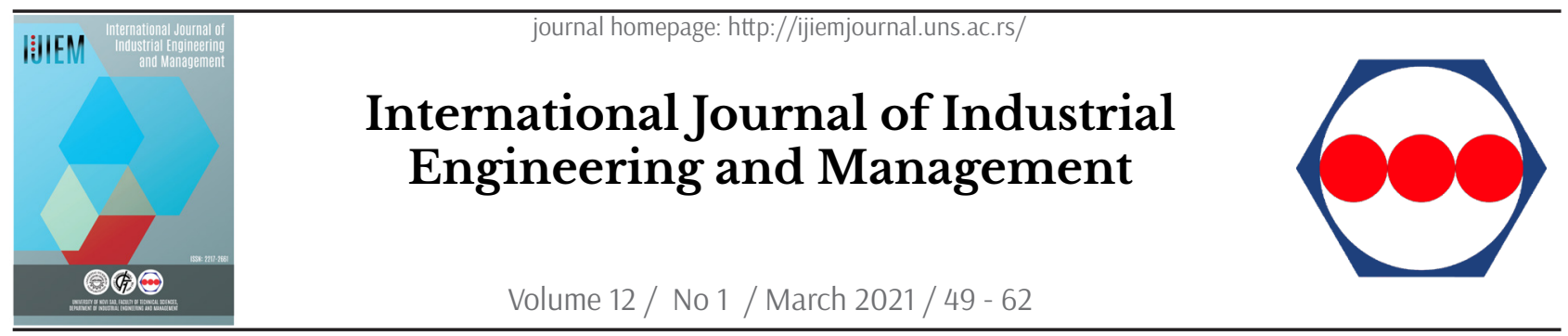

Original research article

\title{
A model with a collaborative approach for the operational management of the supply chain
}

\author{
A. J. Acevedo-Urquiaga a* ${ }^{\star *}$, N. Sablón-Cossío b, J. A. Acevedo-Suárez ${ }^{c}$, A. J.Urquiaga-Rodríguez c \\ ${ }^{a}$ Fundación Universitaria San Mateo, Industrial Engineering Program, Bogotá, Colombia; \\ ${ }^{b}$ Universidad Técnica de Manabí, Postgraduate Institute, Portoviejo, Ecuador; \\ ' Universidad Tecnológica de La Habana "José Antonio Echevarría", Industrial Engineering Faculty, La Habana, Cuba
}

A B STR A C T

The implementation of collaborative approaches in supply chains is an objective of many companies. The proposal of this work is to present a model that favors horizontal integration at the tactical-operational level of the supply chain. The model is based in the principles of logistics flow management; and in the balance of demand, supplies, capacities and stocks. The main contribution of the research is the practical application of collaborative planning as a daily tool for integration between all supply chain echelons. The results obtained in the case studies show that this type of approach improve the efficiency and effectiveness of the logistics system.
ARTICLE INFO

Article history:

Received November 8, 2020

Revised February 13, 2021

Accepted February 17, 2021

Published online February 26, 2021

Keywords:

Collaborative planning;

Supply chain management;

Logistic flow;

Planning

*Corresponding author:

Ana Julia Acevedo-Urquiaga

anajacevedo@sanmateo.edu.co

\section{Introduction}

Several authors agree that to achieve competitive differentiation in the modern environment, efficient and comprehensive supply chain management is required [1-3]. This implies a joint strategy for all supply chain processes, such as efficient resources management and the constant generation of added value for the end customer. A relevant element in supply chain efficiency is the satisfaction of the service levels expected by customers, maintaining adequate levels of inventories [4]. These large inventories generate serious financial and organizational problems for the entities, generating debt chains that demand increasing levels of working capital that cannot be financed [5].
As opposed, even when Information and Communication Technologies allow to obtain the information at any time and point in the supply chain, they are not used to their maximum capacity [6, 7]. This situation is sometimes generated by the inconsistency of organizational solutions with technological innovations (managerial crisis) [8, 9]. The current pandemic situation has shown that not all supply chains, even if they have implemented technologies, have the necessary resilience to adapt quickly to changes in demand or supply [10]. Therefore, it is inevitable to investigate how organizations can use real-time information [11] to coordinate flows in a multi-echelon supply chain [12].

Otherwise, a study of the situation of supply chains and logistics systems in Cuban companies of various 
sectors recognized that; there are difficulties in collaborative supply chain planning where the planning of production, replenishment, logistics, and distribution are separate tasks. Also, the need to developing the vision of the company as a single flow of materials, information, and money is recognized [13, 14].

Taking into account the managerial crisis and the Cuban situation described so far, it is necessary a management model that guarantees:

- A tactical-operative collaborative planning where the planning of production, supply, logistics and distribution are carried out in an integrated way.

- The supply, production and distribution are made according to the customer's demands with the minimum possible inventory.

- The vision of the logistics system as a single flow of materials, money and information.

When the existing management models are analyzed, important advances can be distinguished in the collaborative field. However, none are identified that can fully meet the above-mentioned requirements. Some models are focused on specifics issues, for example, on the minimum operational costs of the supply chain [15]. Others are based on solutions that only cover a part of the chain [16], or a lot of information is needed in advance [17]. There are models that focus on one collaboration variable, such as demand, capacity, cycles, or information management. Others are solved with complex solutions (need very specialized knowledge) such as fuzzy logic or behavioral neural networks.

These models are rather a plan for systematic implementation of improvement programs [18]. In today's dynamic and highly changing environment, it is necessary to take these collaborative efforts to an operational level. Despite this, these models in general, focus on the strategic-tactical analysis [19] than on the tactical-operational management. To enable collaborative planning at the operational level, tools that allow joint decision-making in a fast, consensual, holistic way for the entire logistics system are required [12]. According to the authors, one way to achieve this is to combine the concepts of collaborative management and logistics flow management as part of a single strategy.

Based on this reflection, it is identified as a scientific problem to be solved: What elements and characteristics should make up a collaborative management model of the logistics flow that guarantees an increase in the effectiveness and efficiency of the logistics system? Therefore, the objective of this research is to design a Collaborative Management Model of Logistics Flow (CMMLF) that favors horizontal collaboration in the supply chain at the tactical-operational level and guarantees high efficiency of the logistics cycle.

\section{Theoretical background}

\subsection{Supply chain integration: some clarifications}

The terms coordination and collaboration, or integration and collaboration, are frequently used synonymously. In this paper, the terms are differentiated: integration is the end and the rest of the concepts, the means. By this definition, supply chain integration mechanisms range from weak market negotiations, through cooperation and coordination, to collaboration as the most integrated link between partners [20].

Some authors point out the tendency to increase more complex integration relationships and with the systemic scope of the chain [21, 22]; however, tools are still being developed and implemented to fulfill this promise [23]. In this regard, it is considered that integration is necessary for any business to last. The determining factor is that even with simple mechanisms, the benefits of integration are guaranteed. Most of the efforts of companies focus on internal rather than inter-organizational integration, even though they prefer to focus on more collaborative decision processes instead of employing individual optimization models [24]. In Cuba, the emphasis of business management is also towards internal integration [25], without an adequate external culture.

\subsection{Logistic flow definition}

As seen by different authors, the value creation in the supply chain is achieved through the direction of several flows. In the literature, the material, financial and informative flows are treated from various approaches, but this is not the case with the concept of logistic flow. This is defined as "the coordinated execution of the processes that make up the three flows: the informative, the material, the financial depending on the product demanded by the end customer" [26]; and it constitutes a phenomenon of economic, social, and environmental dimensions.

From the definition of logistics flow, it follows that logistics flow management is nothing more than the planning, executing, and coordinated controlling of 
the three flows. Its main objective is the proper use of resources to create value for customers with the lowest cost and the best possible use of time, and it is one of the elements to develop to achieve competitive advantages [27]. It also covers the operational level where business processes are synchronized; to make the flows as efficient as possible, take advantage of the capacity and reduce the duration of inventories in the supply chain [28]. This includes new forms of cooperation and communication as well as new methods and organizational models [29].

The logistics flow management acts on the logistics system, and it uses the system theory as the basic principle. The logistics system is represented as an open medium that interacts with the environment, favoring the balance of the system. Following this logic, the logistics system becomes a relative concept. It can be as complete as desired: the internal processes of a company, relations with suppliers, an entire supply chain, a region, or a country [30]. It should always be conceived as a harmonic chain of processes that begins and ends with the client, and keep in mind that it is a complex system [31] that seeks complete optimization, not an individual process optimum. In accordance with these definitions, this research analyzes the collaborative management models that are applied in the business [32], inter-company, or supply chain environments.

\subsection{Collaborative planning}

Collaborative planning is the process of joint decision-making for the synchronization of independent and legally autonomous parties, based on the definition of joint objectives and the exchange of knowledge, information, risks, and benefits [33]. In general, authors refer to collaborative planning as centralized decision-making [34]. However, following the logic of the definition, collaborating is working with other partners in joint planning, which does not exclude centralize or decentralize way.

On the other hand, in collaboration, there are several classifications: according to who exercises leadership, the supplier or the client; and the typography of the chain, between pairs of nodes or multi-node (a client and several providers and vice versa) [35]. In the case of the typology, it is considered necessary to add the type of extended relationship [23], where collaboration occurs between three or more nodes, understanding by these several suppliers, producers, marketers, and clients.

The collaborative process at the tactical-operational level aims to stabilize operations through proactive exception management. One of these processes is order management, which in a collaborative environment provides a common ground to communicate and define the status of orders, events, exceptions, and responses [36]. In addition, collaboration at this level should include the estimation and specification of demand in the short-medium term, purchases, inventories, and capacities [37].

On the other hand, the increase in resource and capital limitations makes it necessary to reduce the working capital used. One way to achieve this decrease is to ensure the efficiency of the logistics cycle, that is, the uninterrupted movement of products through the logistics system with the least possible inventory [27, 38].

To achieve the combination of the aforementioned objectives, at the discretion of the authors, there must be a logistics flow management model that allows the collaboration of the participants of the logistics system and that meets the following requirements:

- It plans and controls supplies, production, distribution, and returns in an integrated way.

- It allows determining the moment, term, and quantity in which each process of the logistics system must be executed according to the end customer's requirements.

- It is independent of the type of demand management strategy (pull or push) and the material flow management method used.

- It supports the planning of multi-echelon networks and considers alternative process flows, as well as the efficiency with which they operate (in terms of technology, quality, and performance).

- It ensures the integrated and dynamic balance of demand, supplies, inventories, and the logistics system's capacities at the tactical-operational level.

- It fully manages material, informational and financial flows.

- Identify the possible failures and their effects on the logistics system based on a real-time simulation.

\section{Materials and method}

For the development of a model that meets the requirements set out above, several scientific research methods are used. The historical-logical method allows studying the evolution of planning and control 
methods in supply chains, as well as practical experiences of collaboration in them. Each component of the management techniques described in the literature is analyzed, which allows us to synthesize the common elements that must make up the new model, distinguishing those that are not present in the rest of the models studied. The inductive-deductive method allows applying elements described in the literature to the proposed model, while the analysis of some case studies allows generalizing the results obtained in the application objects.

The semantic modeling is used to develop the concept of the logistics flow collaborative management (section 2.1), and the graphic is used in the representation of the model in a diagram (section 3.1) and the mathematical model implement a set of linear equations for the logistic system balance (section 3.2), added to the equations of the Line of balance technique applied to the logistic system. Likewise, linear algebra is used for the relational representation of capabilities in complex networks of processes (section 3.2).

The model is based on the system approach since it considers the application object as a complete system (section 3.3), be it a company, a logistics system, or a complete supply chain. Finally, simulation is used for decision-making because before making a measure effective, the possible results in the logistics system are analyzed in the model itself.

\subsection{Conceptual basis of the proposed model}

The proposed model is based on the combination of the concepts of collaborative planning and logistics flow. Collaborative planning is the joint planning and control process where all the actors of the logistics system participate and that responds to the common objectives of the system [39]. On the other hand, logistics flow management is the planning, execution, and coordinated control of the three flows (material, information, and finances), [40], through dynamic decision-making in the logistics system direction.

Then, the combination of these concepts defines the logistics flow collaborative management as a means for the planning, execution, and coordinated control of the material, informational and financial flows. Joint and dynamic decision-making between the actors of the logistics system is encouraged to meet the common objectives of effectiveness and efficiency.

\section{Results}

The Collaborative Management Model of the Logistics Flow (CMMLF) is a tactical-operational tool for daily collaborative planning in all supply chain partners.

\subsection{Collaborative Management Model of the Logistics Flow}

The CMMLF is a model to plan and control the logistics system based on the final customer's demand (Figure 1). The core of the model is the Line of balance [41] as a generalization from the produc-

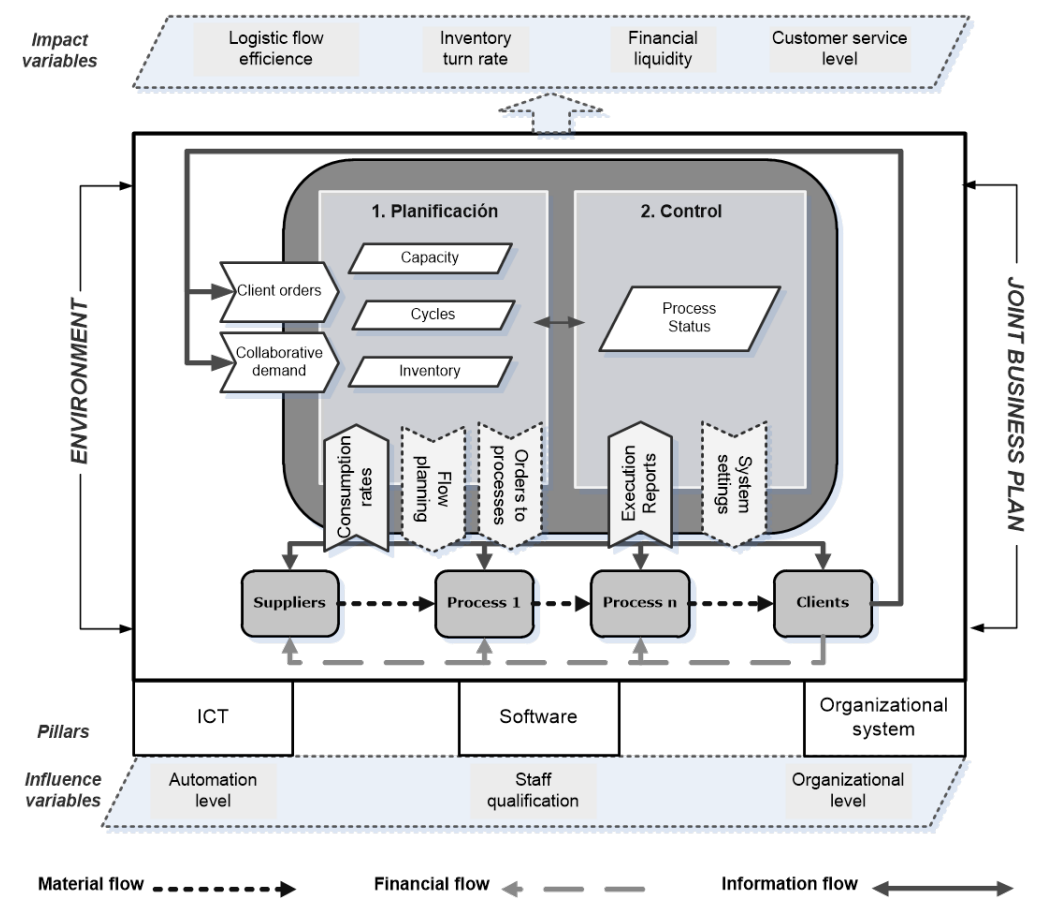

Figure 1. Collaborative Management Model of the Logistics Flow (CMMLF) 
tion planning to the logistics system planning. All processes in the network (sales, distribution, production, supplies, and services providers) are planned in a coordinated way, taking into account lead time, cycle, inventories, capacities, and cost of all of them.

- The planning and control subsystems act in the process network, which is represented by material flows (includes energy and return flow), financial, and informational (includes the feedback of the system).

- Influenced by the economic, political, legal, and environmental location, as well as the automation level, the personnel qualification, and the organizational level.

- The pillars that support it are Information and Communication Technologies, as support for real-time and collaborative management between processes; the computer system, where the mathematical relations of the logistic flow balance are programmed; and the organizational system as an expression of management procedures. These constitute the influence variables for the model application.

- The fundamental inputs of the model are the joint business plan, where collaboration strategies are specified, and collaborative demand as an exit from the strategic level (if a collaboration strategy is defined). Other entries to the planning subsystem are customer orders and consumption rates.

- The planning subsystem generates the flow plan and the orders to the processes from the joint balance of capacities, inventories, and cycles. Once the orders have been executed, the processes send the execution reports to the control subsystem, where the processes' status is updated. In case of deviations between the plan and the actual execution, adjustments are made in the system.

- Impact variables: efficiency of the logistics cycle, inventory turnover, financial resources release, and customer service level.

\subsection{CMMLF objectives and mathematical modeling}

Objectives

(1) Determine the time and quantity to execute in each process based on the requirements of the end customer.

(2) Ensure the integrated and dynamic balance of supplies, inventories, and capacities, to meet the demand of the end customer.

(3) Manage in an integrated way the activities of the material, informative and financial flows.

(4) Simulate the variations of the system conditions and their possible impacts to meet the demand of the end customer.

(5) Achieve relocation of customer orders in response to lack of availability in a process.

\section{Balance equations of the logistics flow}

To verify the proper balance of the logistics system at all times, the system of linear equations described below is formed. These equations relate the balance of demand (internal and external) of inventories, capacities, environmental effects, costs and prices in all the process of the logistic system.

Where:

$\mathrm{i}$ the final or intermediate product of the logistics system $(\mathrm{i}=1,2 \ldots, \mathrm{n})$

j logistics system process $(\mathrm{j}=1,2 \ldots, \mathrm{m})$

j' the process as an internal customer of the logistics system (j’ $=1,2 \ldots, \mathrm{m})$

$\mathrm{k}$ resource or service consumed in system processes $(\mathrm{k}=1,2 \ldots, \mathrm{k})$

s environmental impact of the logistics system processes $(s=1,2 \ldots, s)$

$\mathrm{t}$ time interval $(\mathrm{t}=1,2 \ldots, \mathrm{t})$

$$
P A_{j j^{\prime}}=C L_{j}+C G_{j j^{\prime}} \quad \text { Process cycle and lead time (1) }
$$

$C L_{j} \quad$ Process cycle j (days) $C G_{j j^{\prime}} \quad \begin{aligned} & \text { management cycle between process } j \text { and its direct client } \\ & \text { process j' (days) }\end{aligned}$

$P A_{j j^{\prime}} \quad$ the lead time of the process $j$ with its direct client process j' (days) 


$$
P_{i j j^{\prime} t}=\sum_{i^{\prime}=1}^{n} N C_{i j i^{\prime} j^{\prime}} * P_{i^{\prime} j^{\prime} t_{1}} \quad \text { Process Interrelation (2) }
$$

\begin{tabular}{|ll}
$P_{i j j^{\prime} t}$ & $\begin{array}{l}\text { the volume of the product } i \text { that process } j \text { delivers to the direct client } \\
\text { process } j^{\prime} \text { in the interval } t \text { (units) }\end{array}$ \\
$\qquad C_{i j i^{\prime} j^{\prime}}$ & $\begin{array}{l}\text { The total volume of the product } I^{\prime} \text { delivered by the process } j^{\prime} \text { in the } \\
\text { interval } t\end{array}$ \\
& $\begin{array}{l}\text { product i consumption index in the process } j \text { to obtain a unit of the } \\
\text { product i' in the direct client process } j^{\prime}\end{array}$
\end{tabular}

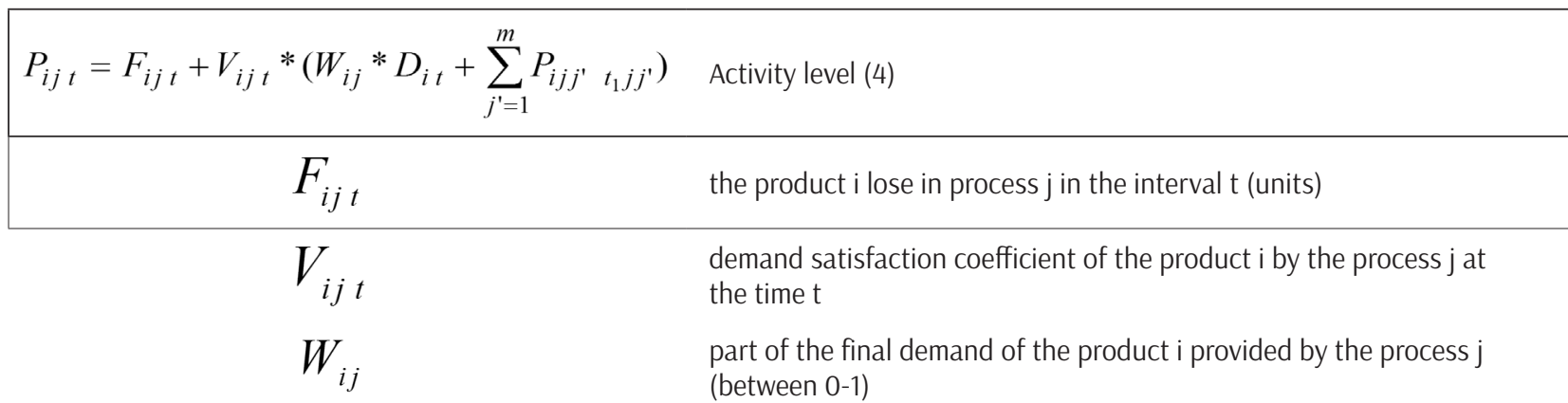

\begin{tabular}{|c|c|}
\hline$D_{i t}$ & $\begin{array}{l}\text { the product i demanded by the customers of the logistics system in the } \\
\text { interval } t \text { (units) }\end{array}$ \\
\hline$P R_{i j t} \leq C A P_{i j t}$ & Capacity balance point (5) \\
\hline$P I$ & $\begin{array}{l}\text { the actual volume of product i processed by process } \mathrm{j} \text { in the interval } \mathrm{t} \\
\text { (units) }\end{array}$ \\
\hline$C A P_{i j t}$ & Process $\mathrm{j}$ capacity for the product $\mathrm{i}$ in the interval $\mathrm{t}$ (units/day) \\
\hline$\sum_{t=t o}^{t c} P R_{i j t} \leq \sum_{t=t o}^{t c} C A P_{i j t}$ & Cumulative Capacity Balance (6) \\
\hline$t_{o}$ & the initial moment of the period analyzed in the logistics system \\
\hline$E_{i j t c}=E_{i j t o}+\sum_{t=t o}^{I c} P R_{i j t}-\sum_{t=t o}^{l c} P_{i j t}$ & Products inventory (7) \\
\hline$E_{i j t}$ & inventory of product $\mathrm{i}$ in process $\mathrm{j}$ in the interval $\mathrm{t}$ (units) \\
\hline$\sum_{t=t o}^{t c} P R_{i j t} \geq \sum_{t=t o}^{t c} P_{i j t}$ & Demand balance (8) \\
\hline$R_{k j t c}=I F_{k j t}+I C_{k j} * \sum_{t=0}^{t c} P R_{i j t}+\sum_{t=0}^{t c} R P_{k j t}-\sum_{t=t o}^{t c} R R_{k j t}+I N_{k j}-I R_{k j t o}$ & Resources balance (9) \\
\hline$R_{k j t}$ & resources $\mathrm{k}$ demand in process $\mathrm{j}$ at time t (units) \\
\hline$I F_{k j t}$ & resource $k$ consumption norm in process $\mathrm{j}$ in the interval $\mathrm{t}$ (units / day) \\
\hline$I C_{k i j}$ & resource $\mathrm{k}$ consumption rate per unit of product $\mathrm{i}$ in process $\mathrm{j}$ \\
\hline
\end{tabular}




$\begin{array}{lr}R P_{k j t} & \text { resource } \mathrm{k} \text { losses in process j at time t (units) } \\ I N_{k j} & \text { resource } \mathrm{k} \text { inventory norm in process j (units) } \\ I R_{k j t} & \text { resource } \mathrm{k} \text { inventory in process j at time t (units) }\end{array}$

\begin{tabular}{cl|}
\hline$R T_{k, t c}=\sum_{j=1}^{m} R_{k j, t c}$ & Total resources' demand (10) \\
\hline$R T_{k t}$ & resource $k$ total demand in the logistics system at time t (units) \\
\hline$I R_{k j, t c}=I R_{k j, t o}+\sum_{t=t o}^{t c} R R_{k j, t}-\sum_{t=t o}^{t c} R_{k j, t}$ & Resources inventory (11) \\
\hline
\end{tabular}

\begin{tabular}{|c|c|}
\hline$R R_{k_{i t}}$ & the actual volume of resources $\mathrm{k}$ received in process $\mathrm{j}$ at time $\mathrm{t}$ (units) \\
\hline$B_{s j t c}=\sum_{i=1}^{n} I E_{s i j} * P R_{i j t}$ & Environmental impact (12) \\
\hline$B_{s j t c}$ & the magnitude of the environmental impact in process $\mathrm{j}$ at time $\mathrm{t}$ \\
\hline$I E_{s i j}$ & impact s generation index per unit of product in process $\mathrm{j}$ \\
\hline$Q_{i j t}=P_{i j t}-\sum_{t o}^{t c-1} P R_{i j t} \geq Q N_{i j}$ & Batch size (13) \\
\hline$Q_{i j t}$ & batch size to be launched from the product $\mathrm{i}$ in process $\mathrm{j}$ at time $\mathrm{t}$ (units) \\
\hline$Q N_{i j}$ & The product i batch size standard in process j (units) \\
\hline$R_{k j t c} \geq Q R_{k j}$ & Resources batch size (14) \\
\hline$Q R_{k j}$ & procurement batch size rule for resource $k$ in process $j$ (units) \\
\hline$C_{j^{\prime} t}=C F_{j^{\prime} t}+\sum_{k=1}^{k} p e_{k} * R R_{k j^{\prime} t}+\sum_{i=1}^{n} p c_{i} * \sum_{j=1}^{m} P_{i j j^{\prime} t}$ & Process cost (15) \\
\hline$C_{j t}$ & process j cost in interval t (pesos) \\
\hline$C F_{j t}$ & fixed cost of process j in interval $t$ (pesos) \\
\hline$p e_{k}$ & resource k price (pesos /unit) \\
\hline$p c_{j}$ & product I price (pesos /unit) \\
\hline$C T_{t}=\sum_{j=1}^{m} C_{j, t}$ & System total cost (16) \\
\hline
\end{tabular}
$C T_{t}$ logistics system's total cost in the interval t (pesos)

\begin{tabular}{|cl|}
\hline$B E_{j t}=\sum_{i=1}^{n} p c_{i} * P_{i j t}$ & Process economic balance (17) \\
\hline$B E_{j t}$ & economic balance of the process $\mathrm{j}$ in the interval t (monetary units) \\
\hline$B E T_{t}=\sum_{j=1}^{m} B E_{j t}$ & System economic balance (18) \\
\hline$B E T_{t}$ & $\begin{array}{l}\text { logistics system's total economic balance in the interval t } \\
\text { (monetary units) }\end{array}$ \\
\hline
\end{tabular}


Equation 2, in the case of logistics systems with complex interrelationships of processes and material back-off, is replaced by the matrix of relational consumption indices expressed in equation 19. It is obtained from the adaptation of the Leontief Input-Output Model [42].

$$
\begin{array}{ll}
(\mathrm{I}-\mathrm{A})^{-1} * \mathrm{Y} & \text { Matrix of relational } \\
& \text { consumption indices (19) }
\end{array}
$$

$\mathrm{A}$ is the square matrix that relates the consumption indices for each pair of linked processes (aij); which translates into the quantity of products that one process must deliver to another for its operation. I is the unitary matrix of the same index as $\mathrm{A}$; and $\mathrm{Y}$ is the column matrix where a unit of demand from the end customer is represented.

\subsection{Model applications}

The model had been applied to different study objects (Table 1); this has allowed validating it based on the results obtained.

As shown in the previous table, the model has been applied in productions and services supply chains. Likewise, the system under planning has gone from internal systems of an enterprise, to a complete supply chain (more than five partners). The applications of the model have been carried out through consultancies projects, in some cases only for demonstration purposes, and in others as part of a multidisciplinary team in the supply chain. These last cases constitute the studies case in which the deductive method is applied to generalize the model and the application procedure.

The implementing process of the model in one of the case studies is briefly described below.

\subsubsection{Implementation in Edible oil supply chain}

The edible oil supply chain is coordinated by a
Commercial Company.

\section{Description of the problem}

The edible oil supply chain is confirmed by national and international suppliers, warehouses for imported final products, two refining and packaging factories, subcontracted transportation companies for distribution and customers. Customers are segmented into commercial customers, wholesalers, and the population that receives a subsidized amount.

After several years of working to improve supply chain management, a Chain Management Council was designed in 2018. This Council is in charge of the strategic, tactical, and operational management, and it is formed by five enterprises representative of each supply chain main echelon.

\section{The solution}

To guide the tactical-operational planning and control process with the model, a procedure is developed, and the mathematical relationships are implemented in Web software.

The implementation of the CMMLF follows the procedure in Figure 2 and each of its phases' results is displayed for the 2018 year. The 1-liter oil's plan is made with the "LFM" software and the results of each step are outlined below.

(A) The 1-liter oil logistic system is shown in Table 2 and the following parameters are determined: sequence, demand percentage that each process executes, column matrix of relational consumption indices, launch and delivery batch sizes, and security coefficients $(\alpha=0.95$ and $\beta=1.05)$.

(B) The total logistics cycle is calculated and it is 129 days and the system management cycle is 188 days.

(C) The planning horizon established is one

Table 1. CMMLF implementation cases. Source: Author's self-made

\begin{tabular}{llll}
\hline Objects & Classification & Product type & Scope \\
\hline Edible oil & Product & standard & supply chain \\
University books loan (library) & service & standard & internal logistic system \\
Nuclear medicine production & product & special & supply chain \\
Medicines supply chain & product & standard & supply chain \\
Metals products distribution & service & standard & Distribution network \\
\hline
\end{tabular}


year, while the planning interval is daily, and it is fulfilled those 365 days $>188$ days.

(D) The daily demand is obtained from dividing the monthly demand between the working days.

(E) The capacities of the processes are determined with a mythology that allow calculate the effective capacity of any process, according to the conditions of 2012.

(F) The accumulated launch and delivery plans are generated, as well as the activity plans of each process.

(G) From the application of the batch sizes, the executing schedule of each process is generated.

(H) Purchase, receipt, production and sale orders are transmitted to the processes.

(I) The accumulative actual execution report of each process for the control interval is reported to the software, using the registered information from the ERP system.

(J) Table 3 shows the control Board with tow delayed processes: "Retractable polyethylene Import" and "Other Customers".

(K) To eliminate arrears, several measures are simulated in the software itself:

- The delay in the process "Other clients" is due to the transport lack. The transportation of the rest of the customers (they are advanced) can be used. This will be reflected in the launch report of "Other Clients" on the deficit amount $(11 \mathrm{t})$ and the delivery of the "Warehouse 2" in the same amount, because this is the near warehouse to the costumers.

- The process "Retractable polyethylene of 75-micron Import" is critical because the hiring was not carried out in the planned time; therefore, the possibility of reducing the cycle is evaluated. Since it is a known

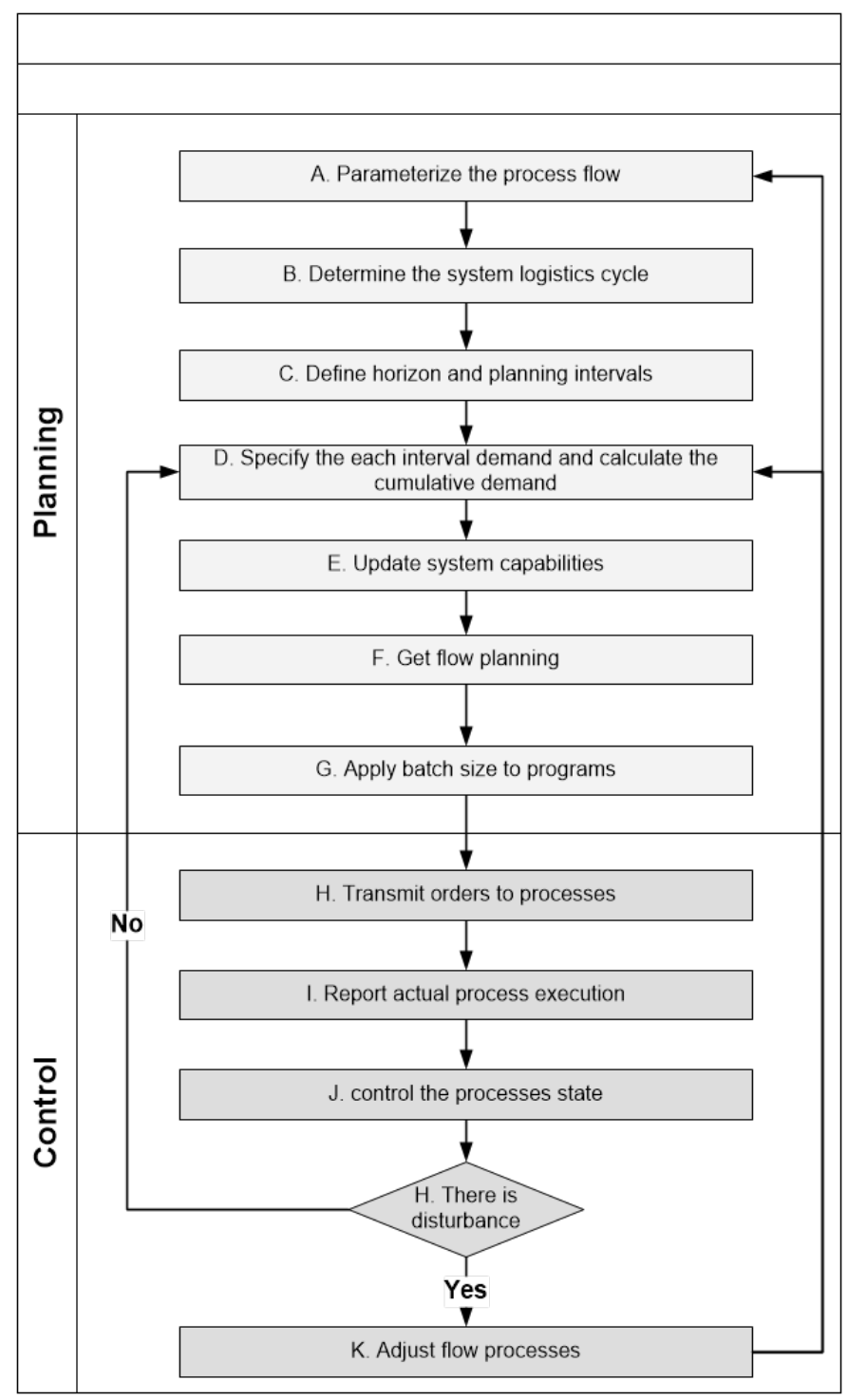

Figure 2. Specific procedure for logistics flow management. Source: Author's self-made 
Table 2. Control Board for control interval 50. Source: Author's self-made

\begin{tabular}{|c|c|c|c|c|c|c|c|c|}
\hline No. & Process & $\begin{array}{l}\text { Lead Time } \\
\text { Release }\end{array}$ & $\begin{array}{l}\text { Plan } \\
\text { Cumulative } \\
\text { Release }\end{array}$ & $\begin{array}{l}\text { Real } \\
\text { Cumulative } \\
\text { Release }\end{array}$ & $\begin{array}{l}\% \\
\text { compliance }\end{array}$ & Deficit & State & $\begin{array}{l}\text { Insured } \\
\text { up to the } \\
\text { interval: }\end{array}$ \\
\hline 1 & Oil Refining Import & 276 & 14388 & 15000 & 104.3 & 0 & IN TIME & 51 \\
\hline 2 & Packaged Oil Import & 276 & 2200 & 4217 & 191.7 & 0 & ADVANCED & 223 \\
\hline 3 & $\begin{array}{l}\text { Retractable polyethylene } \\
\text { import }\end{array}$ & 276 & 95215 & 32080 & 33.7 & 63135 & LATE & $\# \mathrm{~N} / \mathrm{A}$ \\
\hline 4 & Preform national purchase & 235 & 18199 & 95215 & 523.2 & 0 & ADVANCED & 256 \\
\hline 5 & Label national purchase & 235 & 18208 & 25199 & 138.4 & 0 & ADVANCED & 100 \\
\hline 6 & Cap national purchase & 235 & 18159 & 18208 & 100.3 & 0 & IN TIME & 50 \\
\hline 7 & $\begin{array}{l}\text { Cardboard boxes national } \\
\text { purchase }\end{array}$ & 235 & 1537 & 1789 & 116.4 & 0 & ADVANCED & 63 \\
\hline 8 & $\begin{array}{l}\text { Cardboard sheets national } \\
\text { purchase }\end{array}$ & 235 & 132 & 1037 & 785.6 & 0 & ADVANCED & 256 \\
\hline 9 & Packaging 1 & 119 & 3947 & 4500 & 114.0 & 0 & ADVANCED & 75 \\
\hline 10 & Packaging 2 & 120 & 4093 & 4095 & 100.0 & 0 & IN TIME & 50 \\
\hline 11 & Warehouse 1 & 117 & 3874 & 4093 & 105.7 & 0 & ADVANCED & 0 \\
\hline 12 & Warehouse 2 & 118 & 4018 & 3900 & 97.1 & 118 & IN TIME & 46 \\
\hline 13 & Customers Store Chains & 113 & 8144 & 8518 & 104.6 & 0 & IN TIME & 0 \\
\hline 14 & Customers Tourism 1 & 113 & 181 & 300 & 165.7 & 0 & ADVANCED & 120 \\
\hline 15 & Customers Tourism 2 & 113 & 176 & 200 & 113.6 & 0 & ADVANCED & 64 \\
\hline 16 & Prioritized Clients & 113 & 50 & 57 & 114.0 & 0 & ADVANCED & 52 \\
\hline 17 & Other Customers & 44 & 15 & 4 & 26.7 & 11 & LATE & $\# \mathrm{~N} / \mathrm{A}$ \\
\hline
\end{tabular}

Table 3. Simulation of the Control Board for control interval 50 with the proposed measures. Source: Author's self-made

\begin{tabular}{|c|c|c|c|c|c|c|c|c|}
\hline No. & Process & $\begin{array}{l}\text { Lead Time } \\
\text { Release }\end{array}$ & $\begin{array}{l}\text { Plan } \\
\text { Cumulative } \\
\text { Release }\end{array}$ & $\begin{array}{l}\text { Real } \\
\text { Cumulative } \\
\text { Release }\end{array}$ & $\begin{array}{l}\% \\
\text { compliance }\end{array}$ & Deficit & State & $\begin{array}{l}\text { Insured } \\
\text { up to the } \\
\text { interval: }\end{array}$ \\
\hline 1 & Oil Refining Import & 276 & 14388 & 15000 & 104.3 & 0 & IN TIME & 51 \\
\hline 2 & Packaged Oil Import & 276 & 2200 & 4217 & 191.7 & 0 & ADVANCED & 223 \\
\hline 3 & $\begin{array}{l}\text { Retractable polyethylene } \\
\text { import }\end{array}$ & 215 & 95215 & 95300 & 100.1 & 0 & IN TIME & 0 \\
\hline 4 & Preform national purchase & 235 & 18199 & 95215 & 523.2 & 0 & ADVANCED & 256 \\
\hline 5 & Label national purchase & 235 & 18208 & 25199 & 138.4 & 0 & ADVANCED & 100 \\
\hline 6 & Cap national purchase & 235 & 18159 & 18208 & 100.3 & 0 & IN TIME & 50 \\
\hline 7 & $\begin{array}{l}\text { Cardboard boxes national } \\
\text { purchase }\end{array}$ & 235 & 1537 & 1789 & 116.4 & 0 & ADVANCED & 63 \\
\hline 8 & $\begin{array}{l}\text { Cardboard sheets national } \\
\text { purchase }\end{array}$ & 235 & 132 & 1037 & 785.6 & 0 & ADVANCED & 256 \\
\hline 9 & Packaging 1 & 119 & 3947 & 4500 & 114.0 & 0 & ADVANCED & 75 \\
\hline 10 & Packaging 2 & 120 & 4093 & 4095 & 100.0 & 0 & IN TIME & 50 \\
\hline 11 & Warehouse 1 & 117 & 3874 & 4093 & 105.7 & 0 & ADVANCED & 0 \\
\hline 12 & Warehouse 2 & 118 & 4018 & 3911 & 97.1 & 118 & IN TIME & 46 \\
\hline 13 & Customers Store Chains & 113 & 8144 & 8518 & 104.6 & 0 & IN TIME & 0 \\
\hline 14 & Customers Tourism 1 & 113 & 181 & 300 & 165.7 & 0 & ADVANCED & 120 \\
\hline 15 & Customers Tourism 2 & 113 & 176 & 200 & 113.6 & 0 & ADVANCED & 64 \\
\hline 16 & Prioritized Clients & 113 & 50 & 57 & 114.0 & 0 & ADVANCED & 52 \\
\hline 17 & Other Customers & 44 & 15 & 15 & 100.0 & 0 & IN TIME & 48 \\
\hline
\end{tabular}


supplier and negotiations can be carried out in 35 days, a reduction of the process cycle to 95 days and the management cycle to 109 days are achieved, at no additional cost. The amount needed for the launch is $63220 \mathrm{~kg}$ to cover the process deficit and meet the purchase lot.

After the verification of the measure's validity into the Control Board (Table 4), it must return to step B of the procedure where the evaluated measures become effective. In the same way, this is the time to adjust the demand for the next intervals of forecast refinements, consumption changes and internal or external events.

\section{Discussion}

When some supply chain collaborative techniques are analyzed, it is noticed that the most widely studied in literature are CPFR and VMI [43]. Also, when the requirements of collaborative management of logistics flow presented in section 1 are analyzed in these techniques, it is detected that the requirements' compliance is on average $50 \%$ (Table 4); which allows us to affirm that none of the analyzed techniques rep-

Table 4. Relationship matrix between the requirements of collaborative management and the analyzed techniques

\begin{tabular}{|c|c|c|c|c|c|c|c|c|c|c|}
\hline \multicolumn{2}{|c|}{$\begin{array}{l}\text { Techniques/ } \\
\text { Requirements }\end{array}$} & \multirow{2}{*}{$\frac{\text { VMI }}{}$} & \multirow{2}{*}{$\begin{array}{l}\text { CPFR } \\
x\end{array}$} & \multirow{2}{*}{$\begin{array}{c}\text { MRP } \\
\text { II } \\
X\end{array}$} & \multirow{2}{*}{$\begin{array}{c}\begin{array}{c}\text { Line of } \\
\text { balance }\end{array} \\
x\end{array}$} & \multirow[t]{2}{*}{ PFP } & \multirow{2}{*}{$\begin{array}{c}\begin{array}{c}\text { Leontief's In- } \\
\text { put-Output }\end{array} \\
\mathrm{X}\end{array}$} & \multirow{2}{*}{$\begin{array}{c}\text { Mathematic } \\
\text { programing } \\
\mathrm{X}\end{array}$} & \multirow[t]{2}{*}{$\begin{array}{l}\text { Kanban } \\
\text { - JIT }\end{array}$} & \multirow{2}{*}{$\begin{array}{c}\begin{array}{c}\text { Requirements } \\
\text { compliance }\end{array} \\
\mathbf{6}\end{array}$} \\
\hline & balance & & & & & & & & & \\
\hline Planning level & tactical & $x$ & $x$ & $x$ & $x$ & $x$ & $x$ & $x$ & $x$ & 8 \\
\hline & operative & $x$ & & $x$ & $x$ & $x$ & & $x$ & $x$ & 6 \\
\hline \multirow{5}{*}{$\begin{array}{l}\text { Material flow } \\
\text { management } \\
\text { method }\end{array}$} & by existence & $x$ & $x$ & $x$ & & & & $x$ & $x$ & 5 \\
\hline & scheduled & & & $x$ & $x$ & $\mathrm{x}$ & $x$ & $x$ & & 5 \\
\hline & by rhythm & & & & $x$ & & & & & 1 \\
\hline & by order & $x$ & $x$ & $x$ & $x$ & $x$ & $x$ & $x$ & $x$ & 8 \\
\hline & automatic & & $x$ & & & $x$ & & & & 2 \\
\hline \multicolumn{2}{|c|}{ multi-echelon } & $x$ & $x$ & & & & & & & 2 \\
\hline \multirow{2}{*}{ Strategy } & Push & & $x$ & $x$ & $x$ & $x$ & $x$ & $x$ & & 6 \\
\hline & Pull & $x$ & $x$ & & & $x$ & & & $x$ & 4 \\
\hline \multirow{3}{*}{ Flows } & informative & $x$ & $x$ & & & $x$ & & & & 3 \\
\hline & material & $x$ & $x$ & $x$ & $x$ & $x$ & $x$ & $x$ & $x$ & 8 \\
\hline & financial & & & & & $x$ & & & & 1 \\
\hline \multirow{4}{*}{$\begin{array}{l}\text { Processes } \\
\text { planning }\end{array}$} & purchasing & $x$ & & $x$ & $x$ & $x$ & $x$ & & $x$ & 6 \\
\hline & production & & $x$ & $x$ & $x$ & $x$ & $x$ & & $x$ & 6 \\
\hline & distribution & $x$ & $x$ & & & & & $x$ & & 3 \\
\hline & return & & & & & & $x$ & & & 1 \\
\hline \multirow{2}{*}{ Determine } & lead time & & & & $x$ & & & $x$ & & 2 \\
\hline & quantity & $x$ & $x$ & $x$ & $x$ & $x$ & $x$ & $x$ & $x$ & 8 \\
\hline \multirow{4}{*}{ Considers } & quality & & & & & & & & & $\mathbf{0}$ \\
\hline & performance & & & & & & & & & $\mathbf{0}$ \\
\hline & technology & & & & & & & & & $\mathbf{0}$ \\
\hline & $\begin{array}{l}\text { alternative } \\
\text { flows }\end{array}$ & & & & & & & & & $\mathbf{0}$ \\
\hline \multirow{3}{*}{ Integrates } & cycle & $x$ & $x$ & $x$ & $x$ & $x$ & & $x$ & $x$ & 7 \\
\hline & Capacity & & & $x$ & & & $x$ & $x$ & $x$ & 4 \\
\hline & inventory & $x$ & $x$ & $x$ & $x$ & & & $x$ & $\mathrm{X}$ & 6 \\
\hline \multirow{2}{*}{ Control } & in real time & $x$ & $x$ & & $x$ & $x$ & & & $x$ & 5 \\
\hline & simulation & & & & $x$ & $x$ & $x$ & $x$ & & 3 \\
\hline \multicolumn{2}{|c|}{$\begin{array}{c}\% \text { requirements compliance of } \\
\text { each technique }\end{array}$} & $52 \%$ & $55 \%$ & $48 \%$ & $55 \%$ & $55 \%$ & $41 \%$ & $48 \%$ & $45 \%$ & \\
\hline
\end{tabular}

Source: Author's self-made from [27, 41, 42, 44-48] 
resents, by itself, a solution to the research problem.

This analysis in Table 4 shows the existence of overlap in the studied techniques; they have been developed on the same basis, although they adapt to different situations. All models focus on managing the flow of materials at a tactical level and determining the quantities to move. None of them consider the existence of alternative process flows for the products, which makes difficult their application in complex logistic systems. Likewise, there are four requirements that are not met in any of the models analyzed: consideration of the effects of product quality and the ability of technology to ensure it, on the system's capacities; the impact of process performance and the existence of alternative process flows.

The analyzed techniques focus on planning the main flows (products and their components); they do not include the consumed resources in the processes network or the resources and waste generated by them. In this sense, in the CMMLF all types of resources (material, economic, energy, etc.) can be defined as planning objects; and it is based on the Line of balance, which emphasizes material flow management more than inventory management. In addition, it is complemented with Leontief's Input-Output Model for the representation of complex interrelationships between processes. These characteristics contribute to managing the entire logistics system as a single flow.

Table 5 shows the results of CMMLF applications in two studies cases. A comparison of the impact variables is made before and after the use of a planning and control system based on the model (at least for a year). The customer service level is measure differently in each case, depending on the most important attributes for each product or service.

As the earlier table shows, the transformation of the supply chain planning system under a collaborative approach favors its efficiency and effectiveness. The measurement of these variables is carried out in each of the processes involved in the collaboration and in the integrated logistics system.

In the case of edible oil presented above, the average efficiency of the logistics cycle (technology cycle/logistics cycle) and inventory turnover increase, at the same time as the level of customer service. This improvement translates into more than one million financial resources that can be invested in other activities in the supply chain, increasing the efficiency of the system.

\section{Conclusions}

This research constitutes a contribution to the theory of collaborative management of the logistics flow by allowing its conceptualization. The requirements of the collaborative management of the logistics flow constitute the objectives and characteristics of the proposed model. The implementation of these requirements allows the model applicability in different contexts such as those exposed in the requirements of collaborative management of logistics flow.

The CMMLF allows the tactical-operational planning of multi-echelons supply chains in a collaborative context. Likewise, it permits balancing capacities, inventories, cycles, and demand in the system, taking into account capacity and quality restrictions, alternative process flows, constant updating of demands, and internal flows of resources. These constitute the main characteristics that distinguish the CMMLF model from those existing to date.

The combination with blockchain should be considered in future research to improve the information symmetry as well as the speed of its transmission.

Table 5. Results of two CMMLF implementation cases. Source: Author's self-made

\begin{tabular}{|c|c|c|c|c|c|}
\hline \multirow{2}{*}{\multicolumn{2}{|c|}{ VARIABLES }} & \multicolumn{2}{|c|}{ Edible oil } & \multicolumn{2}{|c|}{ University library } \\
\hline & & Before & After & Before & After \\
\hline \multicolumn{2}{|c|}{ Logistics cycle efficiency (\%) } & 63 & 84 & 56 & 98 \\
\hline \multicolumn{2}{|c|}{ Inventory turnovers (times/year) } & 1,9 & 2,3 & 0,8 & 1,4 \\
\hline \multicolumn{2}{|c|}{ Financial liquidity (\$) } & \multicolumn{2}{|c|}{1177894,34} & \multicolumn{2}{|c|}{853667,50} \\
\hline \multirow{4}{*}{$\begin{array}{l}\text { Costumer } \\
\text { service } \\
\text { level }\end{array}$} & Availability by generic (\%) & 26,4 & 95,2 & \multirow[b]{2}{*}{ DIFFERENCE } & "+" 69 \\
\hline & Availability by variety (\%) & 10,2 & 71,2 & & "+" 61 \\
\hline & Student attended (\%) & \multirow{2}{*}{ DIFFERENCE } & "+" 32 & 35 & 67 \\
\hline & Annual Service Amount & & "+" 12722 & 9174 & 21896 \\
\hline
\end{tabular}


Also, the model must be tested in circular economy environments where return flows have a leading role.

\section{Funding}

This research counted with the contribution of colleagues from the Technical University of Dresden and the Wildau Technical University of Applied Sciences, through grants for research stays.

\section{References}

[1] S.-H. Liao, D.-C. Hu, and L.-W. Ding, "Assessing the influence of supply chain collaboration value innovation, supply chain capability and competitive advantage in Taiwan's networking communication industry," International Journal of Production Economics, vol. 191, pp. $143-153, \quad 2017 / 09 / 01 / 2017, \quad$ DOI: https://doi.org/10.1016/j.ijpe.2017.06.001.

[2] W. Green Kenneth, R. A. Inman, E. Sower Victor, and J. Zelbst Pamela, "Comprehensive supply chain management model," Supply Chain Management: An International Journal, vol. 24, no. 5, pp. 590-603, 2019, DOI: $10.1108 /$ SCM-12-2018-0441.

[3] D.-W. Kwak, Y.-J. Seo, and R. Mason, "Investigating the relationship between supply chain innovation, risk management capabilities and competitive advantage in global supply chains," International Journal of Operations \& Production Management, 2018/01/02/ 2018, DOI: 10.1108/ijopm-06-2015-0390.

[4] M. M. Kaibara de Almeida, F. A. Silva Marins, A. M. Pedro Salgado, F. C. Almada Santos, and S. L. da Silva, "The importance of trust and collaboration between companies to mitigate the bullwhip effect in supply chain management.," Acta Scientiarum. Technology, vol. 39, no. 2, pp. 201-210, 2017, DOI: https://doi.org/10.4025/actascitechnol. v39i2.29648.

[5] S. Fernández-López, D. Rodeiro-Pazos, and L. Rey-Ares, "Effects of working capital management on firms' profitability: evidence from cheese-producing companies," Agribusiness, vol. 36, no. 4, pp. 770-791, 2020.

[6] G. Perboli, S. Musso, and M. Rosano, "Blockchain in Logistics and Supply Chain: A Lean Approach for Designing Real-World Use Cases," IEEE Access, vol. 6, pp. 62018--62028, 2018/// 2018, DOI: 10.1109/ access.2018.2875782.

[7] M. Crnjac, I. Veža, and N. Banduka, "From Concept to the Introduction of Industry 4.0," Int. J. Ind. Eng. Manag., vol. 8, no. 1, pp. 21-30, 2017.

[8] A. J. Acevedo Urquiaga, J. A. Acevedo Suárez, and M. I. Gómez Acosta, "El desarrollo del negocio electrónico y la logística," in INFORMÁTICA, La Habana (Cuba), 2011.

[9] S. Chatterjee, G. Moody, P. B. Lowry, S. Chakraborty, and A. Hardin, "Information Technology and organizational innovation: Harmonious information technology affordance and courage-based actualization," Journal of Strategic Information Systems, vol. 29, no. 1, p. 101596, 2020/03/01/ 2020, DOI: $10.1016 /$ j.jsis.2020.101596.

[10] M. S. Golan, L. H. Jernegan, and I. Linkov, "Trends and applications of resilience analytics in supply chain modeling: systematic literature review in the context of the COVID-19 pandemic," Environment Systems and Decisions, vol. 40, pp. 222-243, 2020.

[11] T. Clohessy and T. Acton, "Investigating the influence of organizational factors on blockchain adoption: An innovation theory perspective," Industrial Management \& Data Systems, 2019/08/12/ 2019, DOI: 10.1108/imds-082018-0365.

[12] C. A. Soosay and P. Hyland, "A decade of supply chain collaboration and directions for future research," Supply Chain Management: An International Journal, 2015/09/14/ 2015, DOI: $10.1108 / \mathrm{scm}-06-2015-0217$.

[13] M. I. Gómez-Acosta, J. A. Acevedo-Suárez, Y. Pardillo-Baez, T. López-Joy, and I. Lopes-Martínez, "Caracterización de la Logística y las Redes de Valor en empresas cubanas en Perfeccionamiento Empresarial," Ingeniería Industrial, vol. 34, no. 2, pp. 212-226, 2013.

[14] M. G. Acosta, J. A. A. Suárez, Y. P. Báez, and T. L. Joy, "El desarrollo empresarial como base del éxito de la actualización del modelo económico cubano," Ekotemas, vol. 1, no. 1, pp. 1-15, 2015.

[15] A. Khamseh, E. Teimoury, and K. Shahanaghi, "A new dynamic optimisation model for operational supply chain recovery," Int. J. Prod. Res., pp. 1-16, 2020/12/30/ 2020, DOI: $10.1080 / 00207543.2020 .1842937$.

[16] S. M. Khalili, F. Jolai, and S. A. Torabi, "Integrated production-distribution planning in two-echelon systems: a resilience view," Int. J. Prod. Res., vol. 55, no. 4, pp. 1040-1064, 2017/02/16/ 2017, DOI: 10.1080/00207543.2016. 1213446.

[17] H. Stadtler, "Supply chain management: An overview," in Supply chain management and advanced planning: Springer, 2015, pp. 3-28.

[18] W. Green Kenneth, "Comprehensive supply chain management model," Supply Chain Management: An International Journal, vol. 24, no. 5, pp. 590-603, 2019, DOI: 10.1108/SCM-12-2018-0441.

[19] S. E. Fawcett, G. M. Magnan, and M. W. McCarter, "A THREE-STAGE IMPLEMENTATION MODEL FOR SUPPLY CHAIN COLLABORATION," Journal of Business Logistics, vol. 29, no. 1, pp. 93--112, 2008/03/01/ 2008, DOI: 10.1002/j.2158-1592.2008.tb00070.x.

[20] A. Harrison and R. van-Hoek, Logistics Management and Strategy: Competing through the supply chain, 3ra. ed. Prentices Hall, 2008, p. 467.

[21] C. Stevens Graham and M. Johnson, "Integrating the Supply Chain ... 25 years on," International Journal of Physical Distribution \& Logistics Management, vol. 46, no. 1, pp. 19-42, 2016, DOI: 10.1108/IJPDLM-07-2015-0175.

[22] Auburn University, Logistics 2030 Year Two: Navigating a Disruptive Decade: CSCMP, 2021. [Online]. Available: https://cscmp.org/store/detail.aspx?id=RS20-LOG2030. Accessed on 2021/02/12/.

[23] T. W. Speh, "Assessing the State of Supply Chain Management," in Das Beste der Logistik, H. Baumgarten, Ed. Berlin: Springer, 2008, pp. 247-253.

[24] K. Demeter, L. Szász, and B.-G. Rácz, "The impact of subsidiaries' internal and external integration on operational performance," International Journal of Production Economics, vol. 182, pp. 73-85, 2016/12/01/ 2016, DOI: https://doi.org/10.1016/j.ijpe.2016.08.014.

[25] Decreto 281. Reglamento para la implementación y consolidación del Sistema de Dirección y Gestión Empresarial estatal, Decreto 281, actualizado febrero 2013, 2007.

[26] I. Lopes-Martínez, A. González-Carvajal-Alberto, D. M. Ruíz-Alvarez, Y. Pardillo-Baez, M. I. Gómez-Acosta, and J. A. Acevedo-Suárez, "Problems of code of products that affect the inventory management: Cuban companies case study," Dyna, vol. 81, no. 187, pp. 64-72, 2014.

[27] M. I. Gómez and J. A. Acevedo, La Logística Moderna en la Empresa, 3ra. ed. La Habana: Editorial Universitaria Féliz Varela, 2017, p. 466.

[28] D. J. Bowersox, D. J. Closs, M. B. Cooper, and J. C. 
Bowersox, Supply Chain Logistics Management, 5th ed. McGraw-Hill Education, 2019.

[29] Norwegian Center of Expertise. (2011, 15-08-2009). Material Flow management. Available: http:/www.nceraufoss.com/ind_management/materials_flow_management

[30] M. Wietschel and Lang, Stoffstrommanagement. Frankfurt (Alemania), 2002.

[31] T. Démare, C. Bertelle, A. Dutot, and L. Lévêque, "Modeling logistic systems with an agent-based model and dynamic graphs," Journal of Transport Geography, vol. 62, pp. 51-65, 2017/06/01/ 2017, DOI: https://doi.org/10.1016/ j.jtrangeo.2017.04.007.

[32] A. Ivanisević, A. Lošonc, S. Morača, P. Vrgović, and I. Katić, "Exploring the Business Planning Practices in Smes in a Developing Country," Int. J. Ind. Eng. Manag., vol. 10, no. 1, pp. 105-114, 2019, DOI: 10.24867/ijiem-2019-1-105.

[33] M. Albrecht, Supply Chain Coordination Mechanisms: New Aproaches for Collaborativa Planning (Lecture notes in Economic and Mathematical Systems 628, no. 628). Berlin Heidelberg (Alemania): Springer-Verlag, 2010, p. 176.

[34] A. Kovács, P. Egri, T. Kis, and J. Váncza, "Inventory Control in Supply Chains: A Comparative Analysis of Fundamental Approaches," Fraunhofer Project Center for Production Management and Informatics, Computer and Automation Research Institute, Hungarian Academy of Sciences, Hungary2010.

[35] C. Kilger, B. Reuter, and H. Stadtler, "Collaborative Planning," in Supply Chain Management and Advanced Planning: Concepts, Models, Software, and Case Studies., H. Stadtler and C. Kilger, Eds. 4ta. ed. Berlin, Alemania: Springer, 2008, pp. 1-36. DOI: 10.1007/978-3-540-74512-9.

[36] G. Dudek, Collaborative Planning in Supply Chains. A Negotiation-Based Approach, 2da. ed. Berlin, Alemania: Springer-Verlag, 2009, p. 234.

[37] I. Ribas Vila and R. Companys Pascual, "Estado del arte de la planificación colaborativa en la cadena de suministro: Contexto determinista e incierto," (in español), Intangible Capital, vol. 3, no. 3, pp. 91-121, 2007.

[38] CSCMP. (2013, junio 2011). Supply Chain Management Terms and glossary. Available: cscmp.org/sites/default/files/ user_uploads/resources/.../glossary.pdf

[39] A. J. Acevedo Urquiaga, "Modelo de Gestión Colaborativa del Flujo Logístico," Phd, Resumen de la tesis presentada en opción al grado científico de Doctor en Ciencias Técnicas. , Universidad Tecnológica de La Habana, La Habana Cuba, 2013.

[40] P. Irfani Dian, "Design of a logistics performance management system based on the system dynamics model," Measuring Business Excellence, vol. 23, no. 3, pp. 269-291, 2019, DOI: 10.1108/MBE-01-2019-0008.

[41] L. J. Krajewski, M. K. Malhotra, and L. P. Ritzman, Operations Management: Processes and Supply Chains, Global Edition, 12 ed. Pearson Education Limited, 2018.

[42] D. C. Lay, Linear Algebra and Its Applications, 3ra. ed. Estadus Unidos de América: Pearson Education, 2006, p. 576 .

[43] N. J. S., A. Chilkapure, and V. M. Pillai, "Literature review on supply chain collaboration: comparison of various collaborative techniques," Journal of Advances in Management Research, 2019/10/23/ 2019, DOI: 10.1108/ jamr-10-2018-0087.

[44] F. Panahifar, C. Heavey, P. J. Byrne, and H. Fazlollahtabar, "A framework for collaborative planning, forecasting and replenishment (CPFR)," Journal of Enterprise Information Management, 2015.

[45] A. Mateen and A. K. Chatterjee, "Vendor managed inventory for single-vendor multi-retailer supply chains," Decision Support Systems, vol. 70, pp. 31-41, 2015.
[46] R. Miclo, F. Fontanili, M. Lauras, J. Lamothe, and B. Milian, "An empirical comparison of MRPII and Demand-Driven MRP," IFAC-PapersOnLine, vol. 49, no. 12, pp. 1725-1730, 2016.

[47] C. S. Kumar and R. Panneerselvam, "Literature review of JIT-KANBAN system," Int. J. Adv. Manuf. Technol., vol. 32, no. 3, pp. 393--408, 2007/03/01/ 2007, DOI: 10.1007/ s00170-005-0340-2.

[48] W. L. Theo, J. S. Lim, W. S. Ho, H. Hashim, and C. T. Lee, "Review of distributed generation (DG) system planning and optimisation techniques: Comparison of numerical and mathematical modelling methods," Renewable Sustainable Energy Rev., vol. 67, pp. 531--573, 2017/01/01/ 2017, DOI: 10.1016/j.rser.2016.09.063. 